\title{
The Role and Impact of Australian Refugee Policy in Asia-Pacific Region: From Australia-Cambodia Agreement to Rohingya Crisis
}

\author{
Muhammad Ridho Inzaghi Putra Afira \\ Afiliasi UIN Syarif Hidayatullah \\ Email: ridho.afira18@mhs.uinjkt.ac.id
}

\begin{abstract}
The issues of refugees has been a regional challenges that block the potential of Australia"s role in the Asia-Pacific. This article aims to discuss how Australian refugee policy influences its role in the Asia-Pacific Region. Therefore, this article will examine the background of Australia"s foreign policy towards the Asia-Pacific region from a historical perspective, how Australia made its policy regarding refugees, and discuss some of the latest issues to illustrate how this policy affects Australia"s role in the Asia-Pacific, namely: the agreement with Cambodia (2014), the Manus Island crisis (2017) and Australia"s response to the Rohingya crisis (2017). The author argues that the dynamics of domestic politics in Australia affect Australia's policy towards refugees. In the final analysis, Australia has been trying to limit refugees due to the domestic fear in Australia towards refugees, which has an impact on Australian policy and its role in the Asia-Pacific region.
\end{abstract}

Keywords: South China Sea, China's assertiveness, maritime diplomacy, JapanPhilippines bilateral relations, proactive approach

\begin{abstract}
Abstrak
Masalah pengungsi telah menjadi tantangan regional yang menghalangi potensi peran Australia di Asia-Pasifik. Artikel ini bertujuan untuk membahas bagaimana kebijakan pengungsi Australia memengaruhi perannya di Kawasan Asia-Pasifik. Oleh karena itu, artikel ini akan memeriksa latar belakang kebijakan luar negeri Australia terhadap kawasan Asia-Pasifik dari perspektif historis, bagaimana Australia membuat kebijakannya mengenai pengungsi, dan membahas beberapa masalah terbaru untuk menggambarkan bagaimana kebijakan ini mempengaruhi Australia " Peran di Asia-Pasifik, yaitu: perjanjian dengan Kamboja (2014), krisis Pulau Manus (2017) dan respons Australia terhadap krisis Rohingya (2017). Penulis berpendapat bahwa dinamika politik domestik di Australia memengaruhi kebijakan Australia terhadap pengungsi. Dalam analisis terakhir, Australia telah berusaha membatasi para pengungsi karena ketakutan domestik di Australia terhadap para pengungsi, yang berdampak pada kebijakan Australia dan peran Australia di kawasan Asia-Pasifik.
\end{abstract}

Kata kunci: pengungsi, Australia, kawasan Asia-Pasifik, perjanjian pengungsi Australia-Kamboja, krisis Pulau Manus, krisis Rohingya 


\section{Introduction}

Contemporary, Australia is still debating its position in the international community. Although Australia is indeed located in the Asia-Pacific region, historically most Australians associate themselves with 'western' culture and values. Therefore, any kind of conflict and interactions between Australia and Asia have changed drastically since the founding of Australia in 1901 (Leibo, 2012).

At present, eventhough Australia is involved in Asia-Pacific events, there are still regional challenges that block the potential of Australia's role in the AsiaPacific. One of the most significant problem is the asylum seeker / refugee issues who until now have not been effectively addressed. Issues such as these require cooperation between all countries in the Asia-Pacific, and Australia-as a destination country for refugees - should play an important role in resolving this issue.

Hence, this article aims to discuss how Australian refugee policy influences its role in the Asia-Pacific region. In response to this research question, the author argues that the dynamics of domestic politics in Australia affect policies towards Australian refugees. This also has resulted a limitation of Australia's role in the AsiaPacific region. Thus, this article will; 1) examine the background of Australia's foreign policy towards the Asia-Pacific region from a historical perspective; 2) explain how Australia made its policy regarding refugees; 3 ) discuss some of the latest issues to illustrate how this policy affects Australia's role in the Asia-Pacific, namely: the agreement with Cambodia (2014), the Manus Island crisis (2017) and Australia's response to the Rohingya crisis (2017).

\section{Background of Australia's Foreign Policy towards Asia-Pacific}

Before entering into the refugee case in Australia, the author will provide some basic information about Australia's role in the Asia-Pacific region and Australia's history in this region. For most of the 20th century Australians were afraid of Asia, this was based on the view of those who saw Australia as a European country surrounded by unknown countries (Leibo, 2012). After the Second World War, this fear increased because of the rise of communism. Also, the result of 300,000 Australian troops being tortured by Japan, which made the fear of Australians even greater after the war with Asian countrie (Capling, 2008). 
In this situation, Australia's foreign policy is influenced by the fears of Australian domestic society. After the end of the war, Australia's defense policy and foreign policy were increasingly influenced by the United States. As a result, the former Prime Minister Menzies made a policy called 'Forward Defense' in the 1950s (Connors et al., 2011). Menzies stated that Australia was better defended from a distance than waiting to be attacked (Gurry, 1995). As a result, Australia joined the United States in the Korean and Vietnam War. Furthermore, Australia also took a defensive approach to the Asian region because of the fear of communism during the Cold War period (Edwards, 2014)

A turning point for Australia's relations with other countries in the AsiaPacific was happened in 1969. The cause is Nixon Doctrine from United States which says that they will not defend their allies again including Australia (Connors et al., 2011). In the 1970s the minimal presence of the United States and the United Kingdom in the Asia-Pacific region (604) made Australia aware of becoming more independent. Australia developed relations with countries in Southeast Asia and established diplomatic relations in China in 1972 (Connors et al., 2011).
From the 1980s, the threat of the Cold War began to diminish in Australia because the Soviet Union's power had declined in the Pacific and China began to enter the capitalist market, as a result Australia was no longer afraid of communism in Asia (Connors et al., 2011). In the 1980s Australia's main foreign policy objective was to trade with Asia to benefit from the Asian Economic Miracle. As a result of these economic changes, Japan is the most important Australian export market, which was previously always the United Kingdom (Capling, 2008). At this time 'engagement with Asia' has become an important part of Australia's foreign policy until now (Gurry, 1995).

Increasing engagement in Asia was a major focus of Australian foreign policy during the period under the rule of Labor Bob Hawke and Paul Keating (1983-96). Asia as a priority for Australia's foreign policy aims to 'relocate' the country, economically, militarily to the Asia-Pacific region (Connors et al., 2011). Specifically under Keating's leadership, with the establishment of a 'project' of engagement in Asia, Australia aims to form a new national identity, to become an independent cosmopolitan society residing in Asia, not limited by alliances and historical relations. 
At this time, Australia is focusing on being 'middle power'.

This progress has changed over and over by the Australian prime minister. In 1996 the Australian Coalition Party - the conservative party-was elected and John Howard became prime minister. $\mathrm{He}$ changed Australia's Foreign Policy and reprioritized the role of the United States in Australian policy. Howard said that the ANZUS pact of international treaties was the most important for Australia (Howard, 2001).

Australia's relations with the AsiaPacific region were influenced by three factors under Howard's leadership (Connors et al., 2011). The first factor was the Asian economic crisis in the 1990s. Australia must re-trade with markets outside of Asia. The second factor is the Timor Leste crisis, when tensions between Australia and Indonesia result from Australian assistance during the process of Timor's independence from Indonesia. The third factor is terrorism, with the $9 / 11$ attacks on the United States in 2001 and the Bali bombings in 2002 (Connors et al., 2011). After this incident, Australia began to fear radical Islamic terrorism and some parts of Australian society became Islamaphobia. Because of these three factors, Howard is advancing 'national interest diplomacy'. Here, Australia's foreign policy is very much influenced by the fear of the Australian people. As a result, Australia turned from Asia-Pacific and headed for the United States.

Although Howard shifted Australia's policy from the Asia-Pacific, it became more complex when Labor Prime Minister Kevin Rudd was elected in 2007. Rudd as a former diplomat fluent in Mandarin, and when he was elected, Australia's focus returned to the AsiaPacific. This essay will focus on the period after Rudd until now. Whereas in the past, Australia's policy towards the Asia-Pacific was influenced by opportunities in the region and people's fears.

\section{Australia's Refugee Policy in the Asia- Pacific}

The Asia-Pacific region is home to one of the largest refugee populations in the world. This area is marked by several countries that have not yet signed the 1951 Convention relating to Refugee Status. But even so, the movement of the refugee population continues to increase, with asylum seekers from Afghanistan, Myanmar and Sri Lanka representing the three largest groups and moving irregularly. The majority of these individuals live in the Asia-Pacific (UNHCR, 2017). The Asia- 
Pacific region alone accommodates around 10.6 million people who are refugees with countries as the main host for refugees, Thailand, Malaysia and Indonesia (UNHCR, 2017). While the Southeast Asian region has a protracted refugee problem, Indonesia and Malaysia have become transit centers for asylum seekers on their way to Australia, and Indonesia is most affected by the burden.

Australia is a signatory to the automatic Refugee Convention which has international and legal obligations towards refugees and asylum seekers who arrive on the Australian coast (Taylor, 2017). In 1992, Australia's mandatory detention strategy was implemented by the Keating labor government, this strategy aims to filter out antisocial behavior and strictly regulate the eligibility of individuals to be accommodated to Australian society, the process is still leading to completion.

During the Howard Government, Manus Island and Nauru were established in 2001 as part of Pacific Solution. Initially, the detention solution for asylum seekers was carried out as a short-term response to too many asylum seekers at the time. However, over time, the processing of asylum seekers outside Australia's borders has become the main strategy undertaken by several subsequent governments
(Fraenkel, 2016). Both the Rudd and Gillard governments show that 'offshore' processing is needed to prevent the smuggling of people who tend to be dangerous and exploitative. The two prime ministers were unable to change Australia's policy on refugees because they were faced by domestic pressure in Australia. But during Prime Minister Tony Abbott's administration, Australia shunned its responsibility for its contribution to the problem of migration in the Asia-Pacific, by implementing policies that directly placed a barrier between Australia and other Asia-Pacific countries.

In September 2013 former Australian Prime Minister Tony Abbott launched Operation Sovereign Borders, which had a negative impact on refugees. Operation Sovereign Borders is defined by the Department of Immigration and Border Protection "as" a military-led operation supported and supported by various federal government agencies (Karlsen \& Phillips, 2017). Through this policy, all refugee ships are tapped and returned to their sources. Some refugee ships have also been moved to transit countries such as Indonesia, offshore detention capacities in Nauru and Papua New Guinea (Manus Island) are pushed to the outside. and accommodations in Indonesia exceed their 
limits. Indonesia requests that Australia accept more refugees in accordance with the United Refugee Agency (Elizabeth et al., 2016). Not only are the courtiers having a bad impact on returning asylum seekers, but Australia's relations with Indonesia are threatened because of violations of Indonesia's maritime boundaries by the Australian Navy.

As a middle power in the AsiaPacific region, Australia has inherent obligations to the region, and by default its responsibilities have made Australia underestimated by other Asia-Pacific countries. Historically bipartisan support has supported to help and resolve people who are seeking asylum. The policy was promulgated not only to reduce deaths at sea but apparently due to the existence of Islamophobia and the mistrust that had been embedded in Australian society, fearing who they would eventually call neighbors.

\section{Agreement with Cambodia (2014)}

One of the other Asia-Pacific countries that have links to refugees with Australia is Cambodia. On 26 September 2014 the governments of Australia and Cambodia signed an agreement on refugees. This agreement says that people who have gone to Australia and moved to Nauru by the Australian government will be moved to Cambodia. Former Immigration Minister Morrison said that 40 million Australian dollars had been given to Cambodia to move refugees from Australia. This is in addition to the 79 million Australian dollars Australia has given to Cambodia as assistance (Gleeson, 2016). The agreement has expired and only six refugees were relocated to Cambodia and four chose to move to another country because Cambodia was not suitable (Gleeson, 2016).

Furthermore, there is no certainty that refugees who move to Cambodia will receive full protection under Cambodian law and may not be able to become Cambodians. This agreement took place under the Abbott administration. In accordance with Operation Sovereign Borders, which had previously been discussed, Abbott refused refugees who arrived aboard in Australia. Thus, the Australia and Cambodia agreement is an example of Australia trying to find another place for refugees and as part of Abbott's policy.

In the case of Cambodia, Australia did what was considered irresponsible and received criticism from countries in the Asia-Pacific region. In Asia-Pacific there are 3.5 million refugees, 1.9 million displaced people and 1.4 people without 
citizenship (UNHCR, 2017). Because many people need help in the Asia-Pacific region, all countries must work together to accommodate refugees. By sending refugees who arrived in Australia to Cambodia, Australia refused to find regional solutions and paid other countries to solve this problem. The United Nations High Commissioner for Human Rights, several non-governmental organizations (NGOs), Cambodian opposition leaders and the Cambodian Center for Human Rights all criticized Australia's actions (Gleeson, 2016).

In its refusal to take a role in resolving refugees in the Asia-Pacific region, Australia has reduced its importance in the region. As one of the richer countries in the region, Australia has the responsibility to take a large role in solving regional problems, including the problem of refugees. If Australia cannot help to accommodate refugees, it means that Australia does not deserve a greater role in the Asia-Pacific region. So, because Australia wants to be more important in the Asia-Pacific region, paying Cambodia does not necessarily make Australia more important.

\section{Case Study: Manus Island (2017)}

One case that showed Australia's policy towards asylum seekers in the AsiaPacific region occurred recently in one of the provinces of Papua New Guinea (PNG) named Manus Island. Although this case is still ongoing, there are serious implications for Australia's role in the Asia-Pacific in the future. This case also supports the author main argument that the dynamics of Australia's domestic politics are a more prominent factor. In addition, Australia's policy towards refugees on Manus Island has damaged Australia's image in the AsiaPacific and limited its role in dealing with refugee issues.

In 2016, the PNG Supreme Court ruled that the agreement between PNG and Australia to build and maintain the Manus Detention Center was not in accordance with the PNG Constitution (unconstitutional) (Maguire \& Monaghan, 2017). Under this PNG law, the government has no power over the freedom of prisoners' rights. As a result of this termination, the Australian Government was recently forced to close the Manus Detention Center. But from the start, there was continuing tension and violence between refugees, local residents and the government on Manus Island (Maguire \& Monaghan, 2017). Therefore, almost all 
residents (742 remaining refugees and asylum seekers) reject this closure because the new detention centers available are not safe. This refusal has the potential to result in more severe violence. Until now displaced refugees on Manus Island do not have enough supply of drinking water, food, medical / psychiatric support or other important facilities (Maguire \& Monaghan, 2017).

This case has severely damaged Australia's image as a Human Rights leader in the Asia-Pacific and recently the Australian Government received serious criticism from the UN Human Rights Committee with "chronic non-compliance (Doherty, 2017). Furthermore, the United Nations High Commissioner for Refugees said that Australia must take responsibility and prevent "a looming humanitarian emergency" (Doherty, 2017) which was caused by the closure of the Manus Detention Center while there were hundreds of people living there. It is precisely Australia that created this crisis and therefore if Australia leaves this truly vulnerable human being, Australia means violating their human rights.

It is undeniable, the way of handling cases carried out by the Government of Malcolm Turnbull is very hard. So it can be said, this hard attitude is influenced by domestic political considerations and dynamics, especially the media and public opinion. Some public actors use the media to exploit the vulnerability of the Turnbull government in the country to get certain foreign policy responses. In accordance with the Liberal Party's policy on 'Stop the Boats' discussed earlier, Turnbull also succumbed to domestic pressure and the wishes of the Australian people who were filled with fears of refugees from abroad.

As an alternative route, the Turnbull Administration has tried to move refugees from Manus in various ways. The most visible strategy is an agreement with its traditional ally the United States to accommodate up to 2,000 people currently in custody of Manus or Nauru (McGowan, 2017). But until now there have only been 20 people reported to have been resettled in the US through this process, this agreement itself was criticized by many parties including the US President (McGowan, 2017).

A more suitable offer emerged from New Zealand's Prime Minister, Jacinda Ardern, who offered to help by resettling all refugees from the Manus Detention Center (McGowan, 2017). However, Malcolm Turnbull said he would "consider" the New Zealand offer only if the agreement with the US was completed. This attitude shows 
how Australia still prioritizes its allies (US) even though there are better choices available. In addition, the Australian government now, is reluctant to offer New Zealand because this offer is seen as undermining the fundamental principle of the 'Stop the Boats' policy that is, asylum seekers who enter Australia using ships will never settle in Australia.

So according to the author's argument, it is clear that the attitude of the Turnbull Government towards the Manus Island case is based on domestic dynamics and traditional allies. In the future there is no chance the liberal government will change their policy position because there is a risk of an increase in asylum seekers arriving by ship.

\section{Australia's role in the Rohingya Crisis (2017)}

It has been known beforehand, this crisis was motivated by the Myanmar government that did not recognize the Rohingya population in Myanmar through the Burma Citizenship Law in 1982, on the other hand the Rohingya ethnic group thought that they had lived in the area for a long time. As a result ethnic Rohingya tried to find shelter to other countries because of attacks after attacks by the military and police of Myanmar which caused many casualties (Human Rights Watch, 2000). On September 19, 2017 the UN said that "a vicious cycle of persecution, discrimination, radicalization and violent repression has led to more than 400,000 desperate people to flee, putting regional stability at risk," and this case is still happening today (Bronstein, 2017).

Until this moment, the Australian side only promised dollars to the Rohingya refugees in Papua New Guinea to return to Myanmar (Holmes \& Doherty, 2017). Australia trying to vacate the place by offering 25,000 Australian dollars to refugees who agreed to return to their respective countries, of course returning the Rohingya ethnic back to their original place could endanger them. This was confirmed by Yahya Tabani, a Rohingya refugee prefers to accept the Australian Border Force offer, in an interview with The Guardian which said "I don't want to die in PNG. I prefer to die in Myanmar. Probably Buddhist people are going to kill me as soon as I arrive in Myanmar ... Australia doesn't care if we live or we die," (Hutchens, 2017). Most Rohingya refugees in PNG also think the same, they do not feel the difference with what is in Myanmar, they both feel prisoners and are equally tortured. 
If seen from what is done by the Australian government, Australia does not help many refugees, there are always ways to prevent refugees from entering Australia, for example sending them to PNG, paying third parties to take care of refugee problems, or even returning them to their native countries having problems. This is based on Australia's fear of refugees and indirectly influences their policies towards refugees.

\section{Conclusion}

As the Australian government changed from one period to another, it also produced differences in the policies issued by each Prime Minister. But there is always one thing in common between the policies issued by each Prime Minister, namely the policies issued by the Australian government instead hinder Australia's role to contribute more to the Asia-Pacific Region. In the case we discussed about refugees, Australia relies more on third parties when resolving refugee issues, as the author has discussed, moving refugees to Papua New Guinea, or to Cambodia, or returning them to their home countries. It is very clear that Australia does not want / limit refugees entering their country, this is based on domestic fear in Australia of the 'outside world', which has an impact on Australian policy.
This article has been discussed about Australia's history in the Asia-Pacific region and found that Australia's foreign policy is based on domestic opinion. And it is also admitted that, the dynamics of domestic politics and public opinion influence Australia refugee policies. In 2009, a Conservative Prime Minister Tony Abott was elected with a promise to elect 'to stop the boats'. Following this, the Cambodia agreement, the Manus Island solution and Australia's reaction to the Rohingya crisis are all based on Australian domestic politics. For this reason, Australia's response to the refugee crisis in the Asia-Pacific region is not in line with Australia's strength and ability to accept refugees as citizens. Australia has forced smaller Asian Pacific countries to solve this problem. Thus, Australia is not entitled to have a greater role in in the Asia-Pacific region if Australia cannot contribute more to the issues of refugees in the region.

\section{Reference}

Ardli Johan Kusuma, F. E. (2019). Strategi Diplomasi Kemanusiaan Pemerintah Indonesia Dalam Kasus Krisis Kemanusiaan Yang Dialami Etnis Rohingya Di Myanmar Tahun 2017. MANDALA: Jurnal Ilmu Hubungan Internasional, 151-168.

Bronstein, P. (2017, September 19). UN 
scaling up assistance as number of Rohingya refugees grows to over 400,000 . UN News. https://news.un.org/en/story/2017/09/ 565222-un-scaling-assistancenumber-rohingya-refugees-growsover- 400000

Capling, A. (2008). Twenty years of Australia's engagement with Asia. Pacific Review, 21(5), 601-622. https://doi.org/10.1080/09512740802 457344

Connors, M. K., Davison, R., \& Dosch, J. (2011). The New Global Politics of the Asia Pacific. Routledge. https://doi.org/10.4324/97802038089 93

Doherty, B. (2017, October 19). "Unacceptable": UN committee damns Australia's record on human rights . The Guardian. https://www.theguardian.com/australi a-news/2017/oct/19/unacceptable-uncommittee-damns-australias-recordon-human-rights

Edwards, P. (2014). Australia and the Vietnam War. University of New South Wales Press.

Elizabeth, C. D., Setyawanta, Lt., \& Trihastuti, N. (2016). Kebijakan
Operation Sovereign

Borders

Australia dalam Penanganan Manusia Perahu dan Implikasinya terhadap Kedaulatan Indonesia. DIPONEGORO LAW JOURNAL, 5(3). http://www.ejournals1.undip.ac.id/index.php/dlr/

Fraenkel, J. (2016). Australia's detention centres on Manus Island and Nauru: An end of constructive pacific engagement? Journal of Pacific History, 51(3), 278-285. https://doi.org/10.1080/00223344.201 6.1233802

Gleeson, M. (2016, September 21). The Australia-Cambodia Refugee Relocation Agreement Is Unique, But Does Little to Improve Protection. Migration Policy Institute. https://www.migrationpolicy.org/artic le/australia-cambodia-refugeerelocation-agreement-unique-doeslittle-improve-protection

Gurry, M. (1995). Identifying Australia's Region': From Evatt to Evans. Australian Journal of International Affairs, $\quad 49(1), \quad$ 17-31. https://doi.org/10.1080/10357719508 445143

Holmes, O., \& Doherty, B. (2017, September 19). Australia offers to pay 
Rohingya refugees to return to Myanmar . The Guardian. https://www.theguardian.com/world/2 017/sep/19/australia-offers-payrohingya-refugees-return-myanmar

Howard, J. (2001, February 19). Transcript of the Prime Minister the Hon MP address at Federation Frontline Centrepiece Event, Darwin. Australian Government Department of the Prime Minister and Cabinet. https://pmtranscripts.pmc.gov.au/rele ase/transcript-12321

Human Rights Watch. (2000). Burma/Bangladesh:

Burmese Refugees In Bangladesh Discrimination in Arakan. https://www.hrw.org/reports/2000/bur ma/burm005-02.htm

Hutchens, G. (2017, September 21). Peter Dutton refuses to say if Rohingya refugees being returned to Myanmar. The Guardian. https://www.theguardian.com/australi a-news/2017/sep/21/peter-duttonrohingya-refugees-myanmar

Karlsen, E., \& Phillips, J. (2017). Developments in Australian refugee law and policy: the Abbott and Turnbull Coalition governments (2013-2016). Parliament of Australia.
Leibo, S. A. (2012). East \&Southeast Asia 2012 (45th ed.). Stryker-Post Publications.

Maguire, A., \& Monaghan, G. (2017, October 30). Manus detention centre closure sparks safety fears for refugees. The Conversation. https://theconversation.com/manusdetention-centre-closure-sparkssafety-fears-for-refugees- 84460

McGowan, M. (2017, November 5). Turnbull says he will consider NZ refugee deal only after US resettlements . The Guardian. https://www.theguardian.com/australi a-news/2017/nov/05/kevin-andrewsbreaks-ranks-with-coalition-overnew-zealand-refugee-deal

Taylor, S. (2017). Refugee Protection in the Asia Pacific Region. Rights in Exile Programme.

http://www.refugeelegalaidinformatio n.org/refugee-protection-asia-pacificregion

UNHCR. (2017). Asia and the Pacific. The United Nations Refugee Agency. https://www.unhcr.org/pages/4a02d8e c6.html 